\title{
Original
}

\section{Change in Substrate Specificity of the Periodontal and Kidney Alkaline Phosphatases after Neuraminidase Processing}

\author{
歯根膜および腎臓のアルカリホスファターゼのノイラミニダーゼ \\ 処理後における基質特異性の変化
}

Yoshihisa YAMASHITA * and Tadamichi TAKEHARA *

山下喜 久* 竹 原 直 道*

Received March 25, 1987 ; accepted May 16, 1987

㮽要：歯根膜のアルカリホスファターゼは歯周疾患における骨代钎に重要な役割を演していると考えられ る。しかし，本䤃素の生理的機能については不明な点が多く，生理的基犋の同定すら行われていない。

今回我々は，歯根膜のアルカリホスファターゼをノイラミニダーゼで処理し，その前後の各種リン酸エス テルに対する基質特異性の変化を調へた。また，歯根膜のアルカリホスファターゼと同じニバーサル型の アイソザイムであり，糖镍部分の構造だけが異なる觜䑏のアルカリホスファターゼについても同様に基犋特 異性の変化を調へ，歯根膜のアルカリホスファターゼの結果と比較した。

この結果，ノイラミニターゼにより醉秦の楉鎖部分からシアル酸を除去しても，いずれのアルカリホスフ フターゼの基犋特異性にも著明な変化は認められなかった。このことから，アルカリホスファターゼの糖鎖 中のシアル酸は酵素の基啠に対する親和性に特に重要な役割は演していないものと考えられる。

Koy words: Alkaline phosphatase, Neuraminidase-processing, Sialic acid, Substrate specificity 索引用語 : アルカリホスファターゼ, ノイラミニダーゼ処理, シアル酸, 基算特筫性

\section{Introduction}

There have been many studies") on the resorption of the alveolar bone due to periodontal disease, but the mechanism of this phenomen has not yet been fully explicated. For the ultimate solution of this problem, therefore, it is essential to explicate the mechanism of the resorption and apposition of the alveolar bone in normal periodontal tissue.

It has been said that alkaline phosphatase (AlPase) plays an important role in the resorption and apposition of the bone ${ }^{2)}$. It is, however, unclear what constitutes a physiological substrate of this enzyme in vivo. Moreover, it is not known why calcification does not take place in soft tissues such as the

* Department of Preventive Dentistry, Kyushu Dental College (Director: Prof. Tadamichi TAKEHARA)

* 九州蔽科大学口腔街生学教室（主任：竹原直道教授） 
kidney, the small intestine, and the placenta, where high AlPase activity is observed ${ }^{3)}$. The AlPase in the bone has a different primary structure from that of AlPase in the small intestine and the placenta ${ }^{4}$. This difference could be the basis of the difference between the physiological function of AlPases in hard tissues and in soft tissues. On the other hand, AlPase in the bone is an isozyme almost identical to that in the kidney; these AlPases are different only in the carbohydrate structure of the protein ${ }^{5)}$. It is possible that difference in the carbohydrate structure determines the difference in physiological function between AlPase in the bone and that in the kidney. However, no studies have yet been reported on this.

As we reported previously ${ }^{8}$, the AlPase in the periodontium and that in the bone are immunochemi. cally identical. On the other hand, AlPase in the periodontium differed from that in the kidney, which was an isozyme of the same protein, in the sialic acid content of the carbohydrate structure.

An understanding of how this difference in carbohydrate structures is related to a catalytic function of AlPase in the periodontium and in the kidney would probably lead us to an explication of the physiological function of AlPase in soft and hard tissues.

As the first step in such an investigation, we removed sialic acid from the carbohydrate structures of periodontal AlPase and of kidney AlPase of the same universal form by processing with neuraminidase, and studied the consequent change in substrate specificities of both AlPases.

\section{Materials and Methods}

\section{Enzyme assays}

AlPase activity was assayed at $37^{\circ} \mathrm{C}$ using $6 \mathrm{mM}$ of p-nitrophenylphosphate as a substrate, in $0.1 \mathrm{M}$ glycine- $\mathrm{NaOH}, \mathrm{pH} 11.0$, containg $1 \mathrm{mM}$ of $\mathrm{MgCl}_{2}$ and $0.1 \mathrm{mM}$ of $\mathrm{ZnCl}_{2}$ as previously described ${ }^{7)}$. One unit of enzyme activity corresponds to $1 \mu \mathrm{M}$ of substrate hydrolyzed per minute at $37^{\circ} \mathrm{C}$.

The phosphatase activity of various phosphate esters was examined at $37^{\circ} \mathrm{C}$. The esters were: p-nitrophenylphosphate, $\alpha$-glycerophosphate, $\beta$-glycerophosphate, D-glucose 6-phosphate, $\alpha$-naphtylphosphate, adenosine $5^{\prime}$-phosphate (AMP), O-phospho L-serine and pyridoxal $5^{\prime}$-phosphate (PALP). The assay solution was $0.1 \mathrm{M}$ glycine- $\mathrm{NaOH}, \mathrm{pH} 10$, containing $1 \mathrm{mM} \mathrm{MgCl} 2$ and $0.1 \mathrm{mM} \mathrm{ZnCl}_{2}$. The amount of free phosphate released was estimated using the method of Fiske $e$ al ${ }^{8)}$. Relative activity values were given as percentages, calculated as rates, compared with that of $\mathrm{p}$-nitrophenylphosphate.

\section{Preparation of periodontal and kidney AlPase}

1) The purification of AlPase from rabbit periodontium

A wet weight of $5.1 \mathrm{~g}$ of periodontium was obtained from 40 rabbits and homogenized with a volume of $25 \mathrm{mM}$ Tris- $\mathrm{HCl}, \mathrm{pH} 7.5$, which was nine times as large as that of the sampled material. This homogenate was processed with $1 \%$ Triton $\mathrm{X}-100$ and centrifuged at $100,000 \times \mathrm{g}$ for 60 minutes; the supernatant was collerted as a Triton extract. Using the Triton extract, AlPase was eluted by DEAE-cellulose column chromatography with $25 \mathrm{mM}$ Tris- $\mathrm{HCl}, \mathrm{pH} 7.5$, containing $1 \%$ Triton $\mathrm{X}-100$ and $1 \mathrm{M} \mathrm{NaCl}$. The enzyme solution was concentrated and, in the presence of $1 \%$ Triton $\mathrm{X}-100$, subjected to Sephacryl S-200 gel filtration and Concanavalin A Sepharose column chromatography successively. The details of the process will be published elsewhere. By means of this process, we obtained a partially purified sample of periodontal AlPase with a specific activity of 51.3 units/mg.

2) The purification of AlPase from rabbit kidneys

A wet weight of $100 \mathrm{~g}$ of rabbit kidneys was homogenized with $150 \mathrm{ml}$ of $25 \mathrm{mM}$ Tris- $\mathrm{HCl}, \mathrm{pH}$ 7.5. The homogenate was centrifuged at $100,000 \times \mathrm{g}$ for 60 minutes and the pellet obtained was made into a suspension with $100 \mathrm{~m} l$ of the same buffer. This suspension was processed with an equal volume of butanol, and centrifuged again at $100,000 \times \mathrm{g}$ for 60 minutes. The water-soluble fraction was collected 
and dialyzed against $25 \mathrm{mM}$ Tris- $\mathrm{HCl}, \mathrm{pH} \mathrm{7.5,} \mathrm{until} \mathrm{the} \mathrm{smell} \mathrm{of} \mathrm{butanol} \mathrm{disappeared.} \mathrm{After} \mathrm{it} \mathrm{was} \mathrm{con-}$ centrated, this solution was subjected to DEAE-cellulose chromatography. By means of DEAE-cellulose chromatography, rabbit kidney AlPase was separated at 2 activity peaks ${ }^{\text {g) }}$ one was an isozyme of the universal form eluted at a lower salt concentration, and the other was an isozyme of the intestinal form eluted at a higher salt concentration. The former, after being concentrated, was subjected to Sephacryl S-200 gel filtration and hydroxylapatite column chromatography successively as previously described ${ }^{9}$. After all these procedures, we obtained partially purified kidney AlPase of the universal form with a specific activity of 125 units/mg. Hereafter, this AlPase of the universal form will be referred to as kidney AlPase.

3) The neuraminidase-processing of AlPase

Five hundred $\mu l$ each of the partially purified rabbit periodontal and kidney AlPases $(4.8 \mathrm{units} / \mathrm{ml})$ was mixed with an equal volume of $0.1 \mathrm{M}$ Tris-maleate, $\mathrm{pH} 5.5$, containing $0.5 \%$ Triton $\mathrm{X}-100$ and $1 \mathrm{mM} \mathrm{CaCl}$, Each of the enzyme mixtures was incubated with $500 \mu l$ of insoluble neuraminidase $(0.625$ units/ml, Sigma Type VI-A) adhering to agarose, at $25^{\circ} \mathrm{C}$ for 24 hours.

The effects neuraminidase processing on the AlPase were examined with sodium dodecyl sulfate (SD S) electrophoresi $\mathrm{s}^{10)}$. Removal of sialic acid has been reported to result in slower migration on SDS electrophoresis with AlPase preparation ${ }^{10)}$. Twenty-four-hour incubation of each preparation of periodontal and kidney AlPases with neuraminidase resulted in slower migration. However, the migration distance was not change by further incubation in either case, proving the complete removal of sialic acid from each AlPase preparation.

The incubated materials were centrifuged at $3,000 \times \mathrm{g}$ for 5 minutes and precipitated neuraminidase was removed. The buffer was substituted with $25 \mathrm{mM}$ Tris- $\mathrm{HCl}, \mathrm{pH} 7.5$, using the method of Penefsky ${ }^{11}$.

\section{Other procedures}

Protein determination was carried out using the method of Lowry et al. ${ }^{12)}$.

\section{Results}

Table 1 shows the substrate specificity of periodontal AlPase and that of kidney AlPase, before neuraminidase processing, for various phosphate esters. The values in the Table, represented as percentages, show the activity of AlPase for each phosphate ester relative to that for $\mathrm{p}$-nitrophenylphosphate. The substrate specificity of periodontal AIPase was similar to that of kidney AIPase.

Table 2 shows the specific characteristics of the substrates when reacted with the two AlPase, after neuraminidase processing, in the same manner as depicted in Table 1. No marked differences in neuraminidase processing were observed in the substrates with either AlPase. In both AlPase, however, action on AMP was slightly decreased after neuraminidase processing. This suggested that the affinity of the enzyme for AMP might be augmented by the presence of sialic acid in the structure of carbohydrate.

\section{Discussion}

It is undisputed that AlPase plays an important role in the metabolism of the alveolar bone, especially in calcification. However, the role of AlPase in the calcification of the alveolar bone is unclear.

AlPase exists as an isozyme in one of the 3 following forms: the universal form, the intestinal fo$\mathrm{rm}$, and the placental form; AlPase in the bone is an isozyme of the universal form ${ }^{4}$. We reported that a very large quantity of AIPase was contained in the periodontium, and might have a strong influence on the osseous metabolism of the alveolar bone, and that periodontal AlPase was an isozyme of the same universal form as that found in the alveolar bone. AlPase in the periodontium was different from kidney 
Table 1 Relative activity of AlPase from the rabbit's periodontal ligament and kidney with various phosphate esters

Values are given as percentages, calculated as rates compared with that of p-nitrophenylphosphate.

\begin{tabular}{lcc}
\hline \multirow{2}{*}{ Substrate } & \multicolumn{2}{c}{ Relative Activity(\%) } \\
\cline { 2 - 3 } & $\begin{array}{l}\text { AlPase from } \\
\text { Periodontal } \\
\text { Ligament }\end{array}$ & $\begin{array}{c}\text { AlPase from } \\
\text { Kidney }\end{array}$ \\
\hline p-Nitrophenylphosphate & 100 & 100 \\
a-Glycerophosphate & 60.5 & 62.4 \\
B-Glycerophosphate & 87.7 & 104.6 \\
D-Glucose 6-phosphate & 66.4 & 61.8 \\
$\alpha$-Naphtylphosphate & 85.5 & 87.8 \\
Adenosine 5'-phosphate & 118.3 & 113.3 \\
Pyridoxal 5'-phosphate & 60.1 & 50.2 \\
O.Phospho L-serine & 74.2 & 84.8 \\
\hline
\end{tabular}

Table 2 Relative activity of neuraminidaseprocessed AlPase from the rabbit's periodontal ligament and kidney with various phosphate esters

Values are given as percentages, calculated as rates compared with that of p-nitrophenylphosphate.

\begin{tabular}{lrc}
\hline \multicolumn{1}{c}{ Substrate } & \multicolumn{3}{c}{ Relative } & $\begin{array}{l}\text { Activity (\%) } \\
\text {-processed } \\
\text { AlPase from } \\
\text { Periodontal } \\
\text { Ligament }\end{array}$ & $\begin{array}{l}\text { Neuraminidase } \\
\text {-processed } \\
\text { AlPase from } \\
\text { Kidney }\end{array}$ \\
\hline p-Nitrophenylphosphate & 100 & 100 \\
$\alpha$-Glycerophosphate & 51.4 & 42.6 \\
$\beta$-Glycerophosphate & 87.5 & 82.7 \\
D-Glucose 6-phosphate & 68.2 & 71.1 \\
$\alpha$-Naphtylphosphate & 65.5 & 68.8 \\
Adensine 5'-phosphate & 72.3 & 68.6 \\
Pyridoxal 5'-phosphate & 52.1 & 38.2 \\
O-Phospho L-serine & 68.2 & 73.2 \\
\hline
\end{tabular}

AlPase only in the amount of sialic acid in its carbohjdrate structure. Thus, the two AlPases, though they have the same protein structure, are involved in different functions because of their different carbohy. drate structures: one is involved in osseous metabolism ${ }^{2)}$ and the other in the transportation of material in the uriniferous tubular epithelium ${ }^{13)}$. This fact is very interesting in analyzing the physiological function of AlPase. That is, this fact indicates that it is important to explain what kind of influence the carbohydrate structure of AlPase, especially its sialic acid, has on its kinetics.

As shown in Table 1 and 2, no pronounced alterations were brought about by the removal of sialic acid in the specific characteristics of AlPase for the substrates. This fact indicates that the carbohydrate structure is of little significance in the physiological function of AlPase, and that other factors, such as the form of the enzyme in the membrane, are rather important. However, the fact that, in both AlPases, the affinity for AMP was decreased after neuraminidase processing suggests that the affinity of AlPase for AMP may be augmented by sialic acid.

By doing more experiments of this kind using various phosphate esters, it might be possible to discover a specific substrate where the affinity of AlPase for the substrate is altered by sialic acid. The identi. fication of a substrate whose sensitivity to AlPase can be influenced by sialic acid may lead to the discovery of the physiological functioning of AlPase in vivo.

\section{References}

1) Carranza, F. A. : Glickman's clinical periodontology, Igaku-Shoin/Saunders, International Edition, 1984, pp. 342-360.

2) Robison, R. : The possible significance of hexosephosphoric esters in ossification, Biochem. J., 20 ; 388-391, 1926.

3) McComb, R. B., Bowers, G. N. and Posen, S. : Alkaline Phophatase, Plenum Press,
New York, 1979, pp. 50-51.

4) Lehmann, F.: Evidence of three isozymes (placenta, intestinal and liver-bone-kidney. type) by lectin-binding affinity and immunological specificity, Biochim. Biophys. Acta, 616 ; 41-59, 1980.

5) Goldstin, D. J., Rogers, C. E. and Harris, H.: Expression of alkaline phosphatase loci in mammalian tissues, Proc. Natl. Acad. Sci. U. S. A., 77 ; 2857-2860, 1980. 
6) Yamashita, Y., Sato, M. and Noguchi, T. : Alkaline phosphatase in the periodontal ligament, Archs Oral Biol., 1987, in Press.

7) Bergmeyer, H. U., Gawehn, K. and Grassl, M. : Methods of enzymatic analysis, Academic Press, New York, 1974, pp. 496-497.

8) Fiske, C. H. and Subbarow, Y.: The colorimetric determination of phosphorus, J. Biol. Chem., 66 ; 375-400, 1925.

9) Noguchi, T. and Yamashita, Y.: Rabbit alkaline phosphatases in liver and kidney differ from these of other mammalian, Biochem. Biophys. Res. Commun., 143 ; 15-20, 1987.

10) Kominami, T., Oda, K. and Ikehara, Y. : Induction of rat hepatic alkaline phosphatase and its appearance in serum: Electrophoretic characterization of liver-membranous and serum-soluble forms, J. Biochem., $96 ; 901-$ 911, 1984.

11) Penefsky, H. S.: Reversible binding of $\mathrm{Pi}$ by beef heart mitochondrial adenosine triphosphatase, J. Biol. Chem., 252 ; 2891-2899, 1977.

12) Lowry, O. H., Rosebrough, N. J., Farr, A. L. and Randall, R. J. : Protein measurement with the folin phenol reagent, J. Biol. Chem., 193 ; 265-275, 1951.

13) McComb, R. B., Bowers, G. N. and Posen, S.: Alkaline Phosphase, Plenum Press, New York, 1979, pp. 89-90. 